Review

\title{
Reviewing the Prospects of Sea Fennel (Crithmum maritimum L.) as Emerging Vegetable Crop
}

\section{Massimiliano Renna}

Department of Agricultural and Environmental Science, University of Bari Aldo Moro, via Amendola 165/A, 70126 Bari, Italy; massimiliano.renna@uniba.it; Tel.: +39-080-544-3098

Received: 7 October 2018; Accepted: 26 October 2018; Published: 27 October 2018

\begin{abstract}
Sea fennel (Crithmum maritimum L.), a perennial halophyte typical of coastal habits, is well known for several food and non-food uses. This review presents both the characteristics and ethnobotany as well as the findings, technical advances and potential of sea fennel research with the aim to improve and disseminate knowledge regarding the value and potentials of this halophyte. Current knowledge suggest that sea fennel shows good potential as an emerging crop, being a refined food and also an interesting source of human health compounds and crop protection products. Moreover, sea fennel may be proposed as an alternative and sustainable cash crop also in the context of a saline agriculture regime. On the other hand, some aspects of sea fennel require further understanding; therefore, new research and development activities should be carried out before full commercial exploitation.
\end{abstract}

Keywords: biology; cultivation; ethnobotany; health effects; food use; phytochemistry; proximate composition; SWOT analysis

\section{Introduction}

Sea fennel (Crithmum maritimum L.) is a perennial halophyte also known as samphire, crest marine, marine fennel and rock samphire which grows spontaneously on sandy beaches, maritime rocks, breakwaters and piers (Figure 1) of all the world's coastlines, being particularly abundant along the coasts of Mediterranean countries [1].
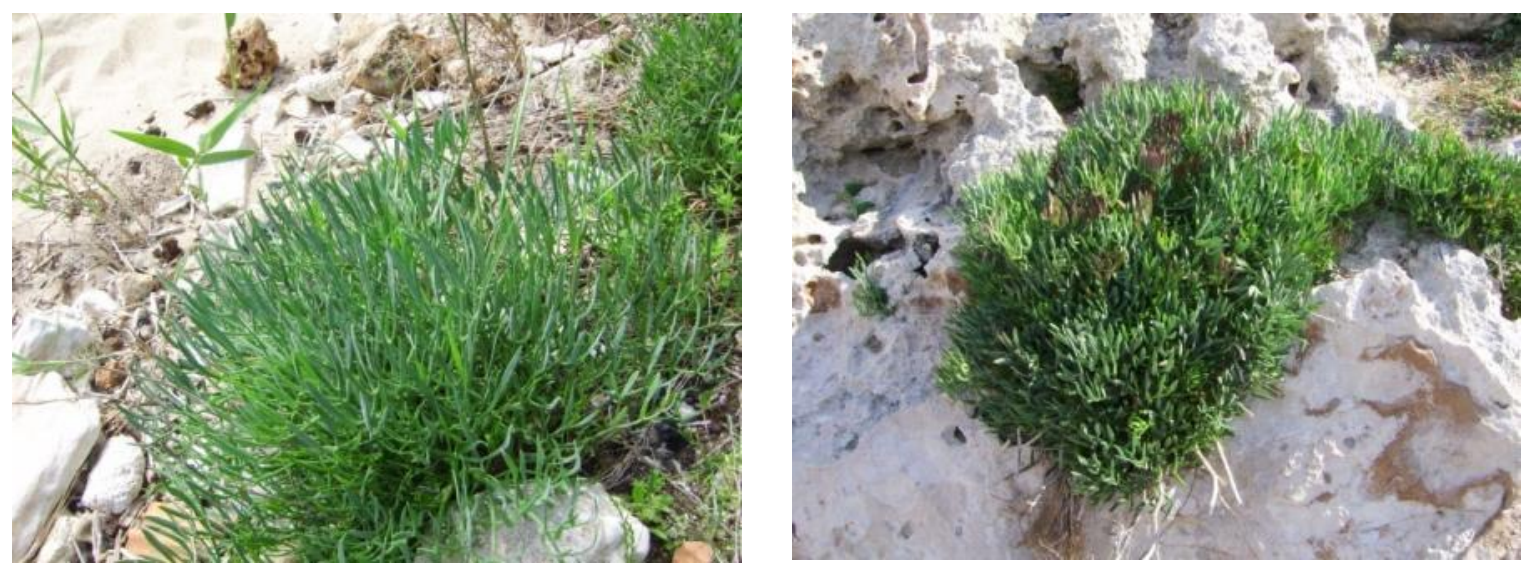

Figure 1. Plants of sea fennel on a sandy beach (left) and maritime rocks (right). Adapted from Renna et al. [2].

In many parts of the world, sea fennel is used as a food ingredient for several traditional recipes. It is especially known for its good sensory traits [3], owed to its high essential oils content [3-5]. 
Furthermore, sea fennel is highly appreciated for both nutritional and medicinal uses, because the leaves contains several healthy compounds [2,6] and the seeds are rich in essential fatty acids [5]. At the same time, sea fennel is currently underutilized for commercial cultivation although it may be considered as a sustainable and promising crop, even if grown on saline soils $[1,6]$.

Today, cultivation of vegetables and several other crops are facing many problems such as temperature increase, low availability of high quality water and soil salinization; these problems are attributable to climate change [7]. In this context, it is most important to have the possibility of proposing alternative crops, such as halophyte species, since they can better adapt under hard conditions, becoming suitable candidates as emerging cash crop and/or medicinal plants [8-10].

Considering the growing scientific interest for this species (Figure 2), in the present review, both characteristics and ethnobotany will be presented as well as the findings, technical advances and potentials of sea fennel research with the aim to improve and disseminate knowledge regarding the value and potential of this halophyte.

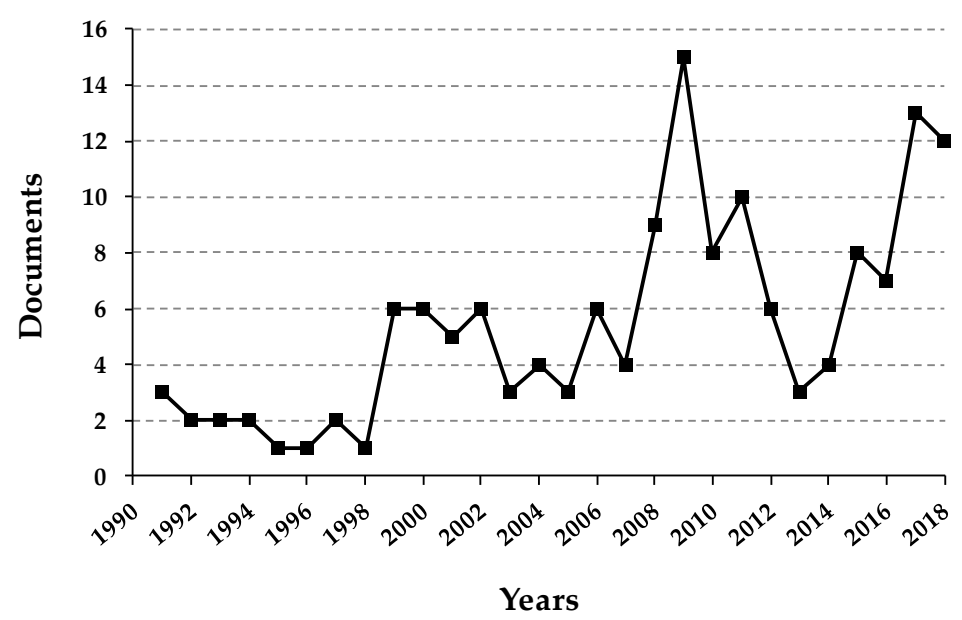

Figure 2. Documents regarding sea fennel published from 1991 to 2018. Documents by type: article $(90.8 \%)$; conference paper (3.9\%); review (3.3\%); note (1.3\%); book chapter $(0.7 \%)$. Data retrieved from Scopus ${ }^{\circledR}$ database by using “Crithmum" AND "maritimum” as key terms for searching.

\section{Biology}

Crithmum maritimum L. is the only species of the genus Crithmum within the Apiaceae family. Sea fennel plants show many branches and succulent leaves (Figure 3) reaching a height up to 60 $\mathrm{cm}$ [11]. The blooming starts in June-September, while the fruits (Figure 3) do not begin to ripen before October-November [1].
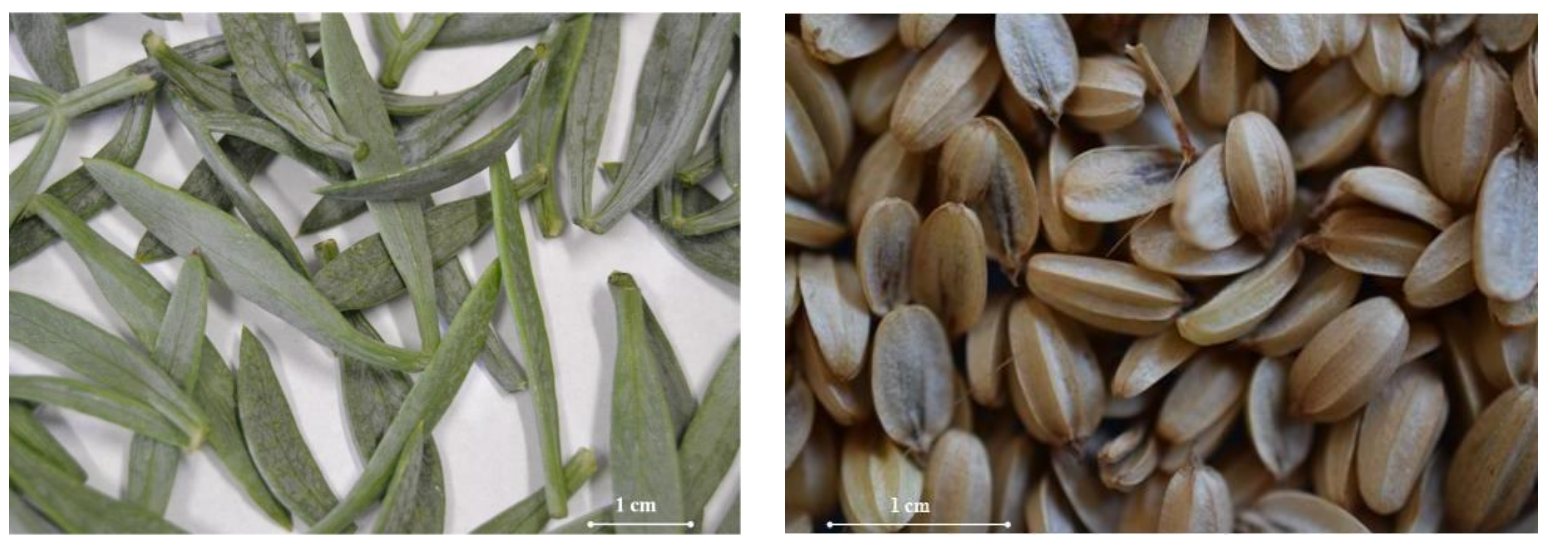

Figure 3. Leaves (left) and fruits (right) of sea fennel. 
C. maritimum L. produces a high amount of viable fruits that can germinate without any inconvenience, especially in distilled water [9]. Nonetheless, despite the fact that this halophyte usually grows near the seawater, seed germination is inhibited when salinities exceed $50 \mathrm{mM} \mathrm{NaCl}[9,10]$. In the natural habitat, sea fennel fruits are always exposed to several ions such as $\mathrm{Na}^{+}, \mathrm{Mg}^{2+}, \mathrm{Ca}^{2+}$, $\mathrm{Cl}^{-}$, and $\mathrm{SO}_{4}{ }^{2-}$. Sodium salts adversely affect seeds germination firstly via the osmotic effect; it is not the case that a high germination recovery can be observed if seeds are transferred in distilled water [1]. Therefore, it is possible to speculate that in nature, although sea fennel seeds remain viable with high salinity conditions, the germination starts at the beginning of the spring, only after salt leaching which is due to the winter precipitations [1]. Another interesting aspect regarding sea fennel seed germination is the fact that it's fruits can be considered a dispersal unit [11]. Both secretory envelope and spongy coat can protect sea fennel seeds from the damage due to potential $\mathrm{Na}+$ and $\mathrm{Cl}-$ accumulation. Furthermore, the high floating capacity together with the germination recovery for explaining the long-distance seed dispersal and the consequent plants growth should also be considered [11].

Regarding the vegetative stage, some research reported that $C$. maritimum $\mathrm{L}$. can be considered as a facultative halophyte [12,13]. By varying the salinity level during the vegetative stage, different eco-physiological responses can be observed. For example, Ben Hamed et al. [14] reported that plant growth was higher by using a nutrient solution with $50 \mathrm{mM} \mathrm{NaCl}$ as compared to a nutrient solution with $300 \mathrm{mM} \mathrm{NaCl}$; in either case, no toxicity symptoms were reported. With a high salinity level, the antioxidant system activity was reduced [13,14], while the accumulation of toxic ions was higher [12]. Alternatively, the photosynthetic activity was maintained in the case of both low and high salinity levels [12]. Halophyte aptitude of sea fennel can be attributed to its ability to preserve tissue hydration and prevent oxidative stress $[1,12,13]$.

\section{Ethnobotanical Knowledge and Food Use}

The term Crithmum is derived from Greek krithe (barley), probably due to the resemblance of fruits (Figure 3) to barleycorns; maritimum is due to its habitat, the sea [1]. In German, sea fennel is named Meerfenchel or Seefenchel; in French fenouil marin, criste-marine, perce-pierr, passepierre; in Italian finocchio marino, cretamo, spaccasassi, bacicci, basiggia, erba di San Pietro, critama; in Spanish hinojo marino or perejil marino; in Turkish kaya koruğu or deniz rezenesi $[3,15]$.

In the past, sea fennel was used in folk medicine to prevent scurvy and for vermifuge and diuretic effects [1]. Today, sea fennel enjoys a good reputation as a traditional remedy in some Mediterranean regions. For example, in Spain, pickled leaves are eaten as a digestive and for its antiscorbutic and diuretic properties [16]. In Northern regions, the sea fennel decoction is used in folk medicine to take care of the urogenital apparatus and liver [17], while in Southern Italy, the same decoction is considered a useful remedy to treat whooping cough and cold [18]. At the same time, for inhabitants of central Italy, the leaf juice is traditionally used for its depurative, diuretic and carminative effect, whereas the fruit infusion is used for its stomachic, digestive and carminative properties [19].

In many countries, the fresh leaves of sea fennel are used to prepare soups, sauces and salads, or they are processed like capers in vinegar; canned sea fennel is registered in the "List of Traditional Agri-Food Product" by the Italian Ministry of Agriculture [2]. The "Rock Samphire Hash" is a traditional dish of the British Isles prepared by using sea fennel leaves mixed with pickled cucumbers and capers. According to Greek legends, the use of sea fennel as a food is lost in the mists of time considering that it was served to Theseus by Hekate [15].

Currently, there is a niche market which offers fresh-cut sea fennel for a broad number of uses in the culinary field [20]. Being an aromatic herb, sea fennel may be used not only as a fresh product but also as a dried herb [21]. Renna and Gonnella [21] reported the culinary use of the sea fennel as a new spice-colorant useful for several gastronomy products. According to these Authors, by using different types of dried sea fennel it is possible to obtain a broad range of applications in food; interesting flavor traits may primarily prevail in some cases, while a peculiar visual effect can be especially perceived in 
other cases. For example, in green tagliatelle (Figure 4), the main coloring effect of the freeze-dried sea fennel was highlighted, while in rice pilaf (Figure 4) with air-dried sea fennel the main spiced effect was reported as a primary trait [21].
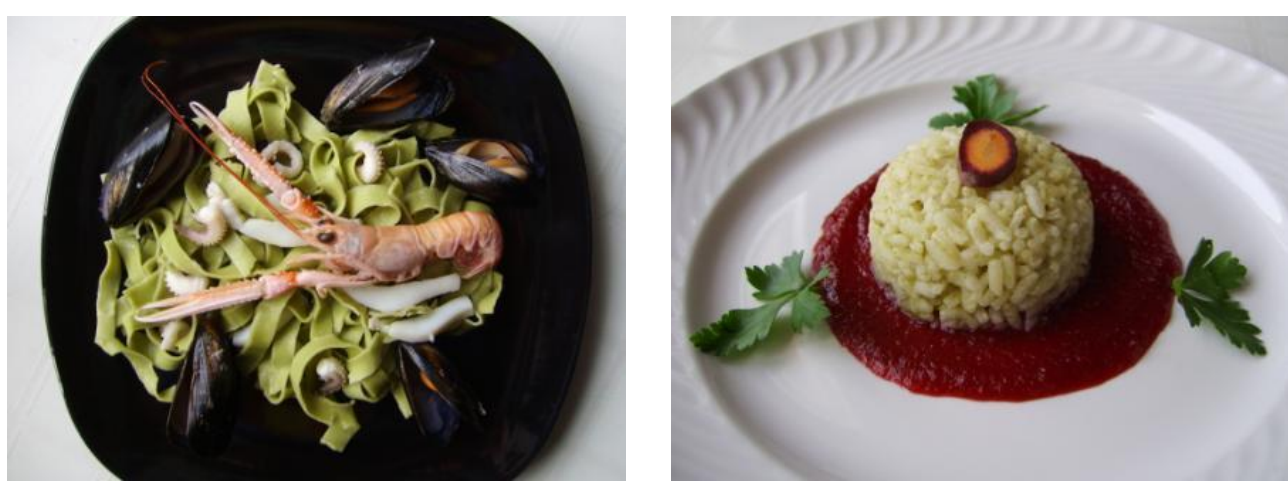

Figure 4. Green tagliatelle (pasta with sea fennel) in marinara style (left) and spiced "dome" (pilaf rice cooked with sea fennel) on puree of apple and purple carrot (right) [21].

With the aim to promote full exploitation of sea fennel, Renna et al. [2] proposed a new dehydrated sea fennel-based product by using several treatments such as air-drying, freeze-drying as well as microwave-drying or microwave-assisted air-drying. These Authors reported that all these treatments enabled a desirable water activity but with a significant reduction of essential oils and chlorophylls content. Both microwave-drying and freeze-drying premised to preserve colour parameters better than other treatments, while freeze-drying enabled the best colouring power [2]. Moreover, after the sensory analysis, the best scores were observed for microwave-dried, microwave-assisted air-dried and freeze-dried samples. In conclusion, results of this study suggest that both microwave-drying and freeze-drying are optimal for preserving qualitative traits of dried sea fennel for food use [2]. Finally, this study highlights the fact that dried sea fennel has impressive aromatic traits as well as an interesting colouring power similar to other food plant-derived colorants [2].

\section{Phytochemistry and Composition}

Proximate composition (content of water, lipid, protein, carbohydrates and ashes) of sea fennel is reported in Table 1.

Table 1. Proximate composition of sea fennel (Crithmum maritimum L.) and common fennel (Foeniculum vulgare L.).

\begin{tabular}{|c|c|c|c|c|c|c|c|}
\hline \multirow{2}{*}{ Crop } & Water & Total Lipid & Protein & Total Carbohydrate & Sugar, Total & Fiber, Total Dietary & Ashes \\
\hline & \multicolumn{7}{|c|}{$\mathrm{g} 100 \mathrm{~g}^{-1} \mathrm{FW}$} \\
\hline Sea fennel ${ }^{1}$ & 87.60 & 0.73 & 1.57 & 7.33 & 0.65 & 3.74 & 2.78 \\
\hline Common fennel $^{2}$ & 90.21 & 0.20 & 1.24 & 7.30 & 3.93 & 3.01 & 1.05 \\
\hline
\end{tabular}

${ }^{1}$ Data retrieved from Bianco et al. [22]; ${ }^{2}$ Data retrieved from National Nutrient Database—United States Department of Agriculture.

Sea fennel is used for several culinary uses also for its fennel-like aromatic traits [2]. Thus, it is interesting to compare the proximate composition of sea fennel with that of common fennel (Foeniculum vulgare L.). Sea fennel shows a lower water content and a higher total lipid and protein content with respect to common fennel (Table 1). Total carbohydrate content seem to be the same for both species, nevertheless, see fennel shows a very low content of sugar and a relatively higher content of fiber with respect to common fennel (Table 1).

Regarding the content of some cations, Bianco et al. [22] found a higher content of sodium and calcium and a lower content of potassium and magnesium in wild sea fennel when compared to cultivated ones (Table 2). 
Table 2. Average content of $\mathrm{Na}^{+}, \mathrm{K}^{+}, \mathrm{Mg}^{2+}$ and $\mathrm{Ca}^{2+}$ in wild and cultivated sea fennel (data retrieved from Bianco et al. [22]).

\begin{tabular}{ccccc}
\hline \multirow{2}{*}{ Sea Fennel Type } & $\mathbf{N a}^{+}$ & $\mathbf{K}^{+}$ & $\mathbf{M g}^{\mathbf{2 +}}$ & $\mathbf{C a}^{\mathbf{2 +}}$ \\
\cline { 2 - 5 } & & $\mathbf{m g ~} \mathbf{1 0 0} \mathbf{g}^{\mathbf{- 1}} \mathbf{F W}$ \\
\hline Wild & 291 & 335 & 28 & 310 \\
Cultivated & 168 & 588 & 41 & 250 \\
\hline
\end{tabular}

This is because, in the marine coastal habitat, wild plants of sea fennel are more exposed to ions such as $\mathrm{Na}^{+}$and $\mathrm{Ca}^{2+}$ with respect to $\mathrm{K}^{+}$. It is well know that potassium, although it is not a constituent of any plant structures or compounds, represents the element required in the highest amounts by plants for both biophysical and biochemical roles. Therefore, especially the higher amount of sodium in wild sea fennel could be a plant's response to alleviating the negative effects of a non-optimal potassium availability level for vegetable tissues. This, considering the role of sodium in replacing potassium for both biochemical and physiological non-specific plant functions.

Beyond the macronutrient and cations content, sea fennel is rich in several chemical constituents. The essential oil of sea fennel contains several volatile compounds such as limonene, $\alpha$-pinene, sabinene, $p$-cimene, $\beta$-terpinene, $\beta$-myrcene, thymol, $\gamma$-terpinene, carvacrol, $p$-cymol, $\beta$-ionone, dillapiole, anisaldehyde, $\beta$-caryophyllene, carvone and myristicine $[1,23]$. These volatile compounds are responsible for some sea fennel aromatic notes such as celery, common fennel and the peel of green citrus [21]. However, the essential oil composition of sea fennel can vary considerably based on the geographic origin of the plants; therefore, it could distinguish different chemotypes: aromatic monoterpenes-type, monoterpene hydrocarbons-type, phenylpropanoids-type and their intermediate forms [3,4,24-32]. Moreover, also other factors such as the life-cycle stage of the plant and year of collection, can affect the essential oil composition in sea fennel [3,4]. For example, Pateira et al. [4] found that the percentage of diallopil in sea fennel harvested from the same location and the same year was $42.1,33.3$ and $35.1 \%$ for vegetative, flowering and fruiting stage respectively. At the same time, these Authors found that the percentage of diallopile in sea fennel harvested during the vegetative stage was 42.1 and $14.5 \%$ in two different years of collection [4]. Apart from the composition, it is important to highlight that the amount of essential oils in sea fennel reaches about $0.8 \%$ in fruits and from 0.15 to $0.3 \%$ in leaves [1].

The oils extracted from C. maritimum L. leaves contain interesting amounts of fatty acids of the $\omega-3$ and $\omega-6$ series; their percentage (on dry weight basis-DW) reaches $2.02 \%$ for neutral lipids, $0.57 \%$ for the glycolipids and $0.26 \%$ for the phospholipids [33]. On the other hand, seeds contain about $44 \%$ (on DW) of oil, which is mainly constituted by oleic (78.6\%), linoleic (15.4\%) and palmitic acid (4.8\%). This composition is similar to other oil types such as olive and canola, highlighting the high quality of oils extracted from sea fennel seeds [23].

Sea fennel leaves also contain a significant amount of other compounds such as ascorbic acid, carotenoids, tannins and flavonoids [15,33-35]. The content of vitamin C, flavonoids, tannins, total polyphenols and carotenoids in the aerial parts of sea fennel is reported in Table 3. It is interesting to highlight that this halophyte shows high phenolic contents compared to other crop species [36]. Chlorogenic acid and phenolic acids can be considered the most commonly detected phenolic compounds [37]. However, total phenols content of sea fennel can vary considerably based on the vegetation period. 
Table 3. Content of vitamin C, flavonoids, tannins, total polyphenols and carotenoids in the aerial parts of sea fennel.

\begin{tabular}{ccc}
\hline Compound & Value & References \\
\hline Vitamin C & $76.6{\mathrm{mg} 100 \mathrm{~g}^{-1} \mathrm{FW}}^{-1} \mathrm{FW}$ & Franke [15] \\
Flavonoids & $2.3 \mathrm{mg} \mathrm{g}^{-1} \mathrm{DW}$ & Maleš et al. [35] \\
Tannins & $6.8 \mathrm{mg} \mathrm{g}^{-1} \mathrm{DW}$ & Maleš et al. [35] \\
Total polyphenols & $2.3 \mathrm{mg} \mathrm{g}^{-1} \mathrm{DW}$ & Maleš et al. [35] \\
Carotenoids & $33.8{\mathrm{mg} 100 \mathrm{~g}^{-1} \mathrm{DW}}$ & Guil-Guerrero et al. [33] \\
\hline
\end{tabular}

For example, Mekinić et al. [38] reported that during April, sea fennel extract contained the highest amount of phenolics and chlorogenic acid in respect to other months. The presence of diosmin and hesperidin was reported by Cornara et al. [39], while other Authors [37] reported high amounts of caffeic, gallic, rosmarinic, vanillic, and p-coumaric acids as well as a small content of trans-cinnamic and trans-2-hydroxycinnamic acids. A low amount of apigenin, rutin, quercetin-3-galactoside, catechin, epicatechin, epigallocatechin is also reported [37,40]. Meot-Duros et al. [40] reported the presence of falcarindiol in sea fennel leaves, while other Authors reported small amounts of some coumarins [23]. Figure 5 reports the chemical structure of some biologically active phenolic compounds found in sea fennel. Apart from phenolic compounds, other water-soluble compounds like sucrose, glucose and organic acids were reported [36].

Finally, another important aspect to highlight is the fact that sea fennel extract was proven to be highly sensitive to extraction techniques and extraction conditions. In a study aimed to evaluate the efficacy of two extraction techniques from C. maritimum L., Costa et al. [41] compared ultrasound-assisted extraction (UAE) and supercritical fluid extraction (SFE). The amount of total extract, contents of total phenolics and flavonoids and antioxidant capacity of the extracts were measured. The authors reported that by using UAE the amount of extracted antioxidants was approximately 10-fold higher compared to SFE. In particular, UAE was able to obtain the highest content of total phenols (23.44 mg Gallic Acid Equivalent g DW ${ }^{-1}$ ) and flavonoids (16.63 mg Quercetin Equivalent $\mathrm{g} \mathrm{DW}^{-1}$ ). For UAE, best conditions were: temperature $50{ }^{\circ} \mathrm{C}, 20 \mathrm{~min}$ extraction time, 1:30 ratio solid:solvent and $40 \%(v / v)$ ethanol concentration. The best conditions for SFE were found at $50{ }^{\circ} \mathrm{C}$ and 300 bar pressures with $40 \%(v / v)$ ethanol concentration.

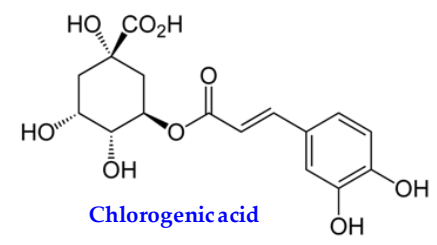<smiles>O=C(O)c1cc(O)c(O)c(O)c1</smiles><smiles>O=c1c(O)c(-c2ccc(O)c(O)c2)oc2cc(O)cc(O)c12</smiles><smiles>COc1cc(/C=C/C(=O)O)ccc1O</smiles><smiles>COc1ccc(-c2cc(=O)c3c(O)cc(OC4OC(COC5OC(C)C(O)[C@H](O)C5O)[C@@H](O)[C@H](O)[C@H]4O)cc3o2)cc1O</smiles>

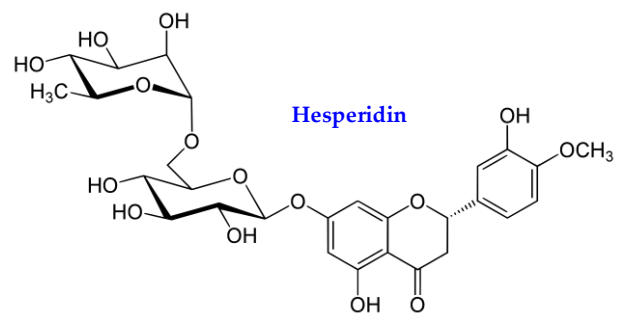<smiles>O=c1ccc2ccccc2o1</smiles>

Figure 5. Chemical structure of some biologically active phenolic compounds found in sea fennel. 


\section{Biological Activity}

Some biological activities of sea fennel are reported in Table 4.

Table 4. Literature regarding biological activity of sea fennel.

\begin{tabular}{|c|c|c|}
\hline Biological Activity & Product Type & References \\
\hline Antibacterial & Essential oils & $\begin{array}{c}\text { Loizzo et al. [42] } \\
\text { Mekinić et al. [43] }\end{array}$ \\
\hline Antibacterial & Plant extract & $\begin{array}{l}\text { Meot-Duros et al. [39] } \\
\text { Meot-Duros et al. [44] } \\
\text { Loizzo et al. [42] } \\
\text { Mekinić et al. [43] } \\
\text { Houta et al. [35] }\end{array}$ \\
\hline Antifungal & Essential oils & Glamoclija et al. [27] \\
\hline Antifungal & Plant extract & $\begin{array}{c}\text { Meot-Duros et al. [44] } \\
\text { Houta et al. [35] }\end{array}$ \\
\hline Antioxidant & Essential oils & $\begin{array}{l}\text { Loizzo et al. [42] } \\
\text { Mekinić et al. [43] }\end{array}$ \\
\hline Antioxidant & Plant extract & $\begin{array}{c}\text { Meot-Duros et al. [44] } \\
\text { Loizzo et al. [42] } \\
\text { Mekinić et al. [43] } \\
\text { Houta et al. [35] }\end{array}$ \\
\hline Cytotoxic against tumor cells & Plant extract & $\begin{array}{l}\text { Meot-Duros et al. [39] } \\
\text { Pereira et al. [41] }\end{array}$ \\
\hline Insecticide & Essential oils & $\begin{array}{c}\text { Tsoukatou et al. [28] } \\
\text { Polatoglu et al. [32] } \\
\text { Pavela et al. [21] }\end{array}$ \\
\hline Milk production stimulant & Whole plant & $\begin{array}{c}\text { Viegi et al. [45] } \\
\text { Cornara et al. [19] }\end{array}$ \\
\hline Vasodilator & Plant extract & Mekinić et al. [43] \\
\hline
\end{tabular}

Sea fennel contains interesting bioactive compounds that show antiradical, peroxidation inhibition and reducing power abilities [34,42]. In a study aimed to evaluate the antioxidant activity of different parts of sea fennel plant, Houta et al. [34] found that the methanolic extract of seeds displayed the highest DPPH. scavenging ability with the lowest IC50 value $\left(406 \mu \mathrm{g} \mathrm{mL}^{-1}\right)$ followed by leaves, flowers and stems (IC50 value of 500, 706 and $726 \mu \mathrm{g} \mathrm{mL}-1$, respectively). According to some Authors [34,43], the strong antioxidant activity of the sea fennel extracts is due to the high content of phenolic compounds. However, it is important to highlight that both the content and composition of these compounds are highly influenced by the plant's physiological stage [37]. The very high antiradical activity of sea fennel extracts reflects a high health potential in the context of functionality and antioxidant activity of food [32]. Apart from the soluble compounds, essential oils also show interesting antioxidant activity [44], although to a lesser extent [45]. For example, Mekinić et al. [45] found that the ferric reducing/antioxidant power (FRAP) of essential oils was of 22.0, 42.0 and $8.4 \mu \mathrm{mol} \mathrm{Fe}{ }^{2+} \mathrm{L}^{-1}$ respectively for flowers, stems and leaves, while the FRAP of ethanolic extracts was of $16,065.6,3009.4$ and $17,335.0 \mu \mathrm{mol} \mathrm{Fe}{ }^{2+} \mathrm{L}^{-1}$ respectively for flowers, stems and leaves. The same Authors found that the DPPH. scavenging ability (expressed as inhibition percentage of DPPH radical) of essential oils was of 2.8, 2.8 and $2.6 \%$ respectively for flowers, stems and leaves, while the the DPPH. scavenging ability of ethanolic extracts was of $61.0,13.0$ and $61.8 \%$ respectively for flowers, stems and leaves [45].

Sea fennel contains a significant amount of fatty acids within the $\omega-3$ and $\omega-6$ series; therefore, its use as a food could have beneficial effects toward the prevention of coronary heart diseases [33]. Mekinić et al. [45] reported a high vasodilatory activity when both plant extracts and essential oils were used. These Authors found that the maximal vasodilatory effect (expressed as the percentage 
decrease of the noradrenaline-precontracted rat aortic rings) for essential oils was $23.0 \%$, while for ethanolic extract was $44.7 \%$ [45].

Moreover, sea fennel showed significant cytotoxic activity against some tumor cell lines such as mouse lymphocytic leukemia, lymphocytic leukemia and human myeloma without cytotoxic effects against some different mammalian cell lines [43] and normal human intestinal cells [40].

Another interesting aspect of sea fennel is its antimicrobial activity [34] being able to inhibit the growth of both Gram-positive and Gram-negative human pathogenic bacteria. Meot-Duros et al. [40] found that falcarindiol isolated from sea fennel leaves strongly inhibited the growth of Micrococcus luteus and Bacillus cereus, with a minimum inhibitory concentration (MIC) value of $50 \mu \mathrm{g} \mathrm{mL}^{-1}$.

Meot-Duros et al. [46] also reported a strong antimicrobial activity of sea fennel extract against Salmonella arizonae, Erwinia carotovora, Pseudomonas fluorescens, P. marginalis and Candida albicans.

In a study aimed to evaluate antitrypanosomal compounds in essential oils from the Apiaceae family, Ngahang Kamte et al. [47] reported that the essential oils from C. maritimum L. could be considered as a reservoir of substances to be used as leading compounds for the development of natural drugs for the treatment of Human African Trypanosomiasis.

Some authors $[17,48]$ reported the veterinary use of sea fennel to integrate rabbit diet and stimulate milk production. In a study aimed to evaluate antifungal activity of sea fennel, essential oils against mushroom pathogen Mycogone perniciosa Mang., Glamoclija et al. [25] found better antifungal activities of essential oils than the commercial fungicide Prochloraz-Mn. It is also interesting to report that sea fennel could be used as a potential source of natural insecticides considering that essential oils showed a lethal effect against Pheidole pallidulav L. [27], Sitophilus oryzae L. and Oryzaephilus surinamensis L. [30]. Also, Pavela et al. [19] evaluated the insecticide effect of sea fennel, highlighting that essential oils rich in phenylpropanoids like dillapiole and myristicin show the best lethal effect against the larva of Spodoptera littoralis (Boisd.) and Culex quinquefasciatus Say, while essential oils rich in monoterpenes show only an inhibitory effect.

\section{Cultivation}

Although sea fennel can be considered as a promising crop, only little information is available in the literature regarding its growing techniques.

It is well known that factors such as temperature, salinity, and light conditions have a significant effect on the seed germination process and seedling production of sea fennel [49]. Marchioni-Ortau and Bocchieri [50] showed that the optimal conditions for seed germination of a Mediterranean population of sea fennel were a temperature of $20^{\circ} \mathrm{C}$ and absence of light by using deionized water or at a very low salt concentration. It is important to highlight that the optimal conditions for germination of seed populations from the Atlantic coast seem to be very different from those reported for sea fennel populations from the Mediterranean basin [50]. In order to improve sea fennel seed germination for producing sea fennel seedlings, some interesting information is available in the literature. For example, Atia et al. [51] reported that the use of red light and nitrogen-based compounds can significantly promote and accelerate germination. At the same time, pretreatment of seeds with L-ascorbic acid or ethanol can improve the seed germination rate by 30\% [52]. At any rate, seed priming may be carried out in order to accelerate seed germination as well as to obtain a better homogeneity as a consequence of an improved early seedling growth [53].

Some Authors $[13,54]$ reported the production of sea fennel seedlings by in-vitro techniques without negatively affecting the performance of root and plant growth.

In order to assess salt response of sea fennel, Hamed et al. [12] cultivated this halophyte in pots filled with sand by using nutrient solutions at different $\mathrm{NaCl}$ concentrations $(0,50,100,150,200$, and $300 \mathrm{mM}$ ). Plants were harvested 13 weeks after transplanting while $\mathrm{NaCl}$ treatments started 8 weeks after transplanting. These Authors reported a biomass production of 1 and $13 \mathrm{~g} \mathrm{DW}$ plant $^{-1}$ by using a nutrient solution with 300 and $0 \mathrm{NaCl} \mathrm{mM}$, respectively. Likewise, leaf area increased from 100 to more than $600 \mathrm{~cm}^{2}$ plant $^{-1}$ with the same salinity levels, highlighting that sea fennel is moderately 
tolerant to salinity. Therefore, it is possible to consider C. maritimun L. as a facultative halophyte, since high growth does not necessary mean high salinity levels [12].

Montesano et al. [6] evaluated the effect of posidonia compost-based substrates as a potential growing media for potted sea fennel cultivation (Figure 6). Following the harvest carried out 60 days after transplantation, these Authors found an average yield of about $5.4 \mathrm{~g}$ DW plant $^{-1}$ without significant differences between various substrates, suggesting the possibility to replace peat substrates with renewable media without a negative effect on yield and quality. Furthermore, these Authors hypothesized that the halophyte aptitude of sea fennel can help to overcome the limitations posed by the high salinity of some compost-based growing media [6].

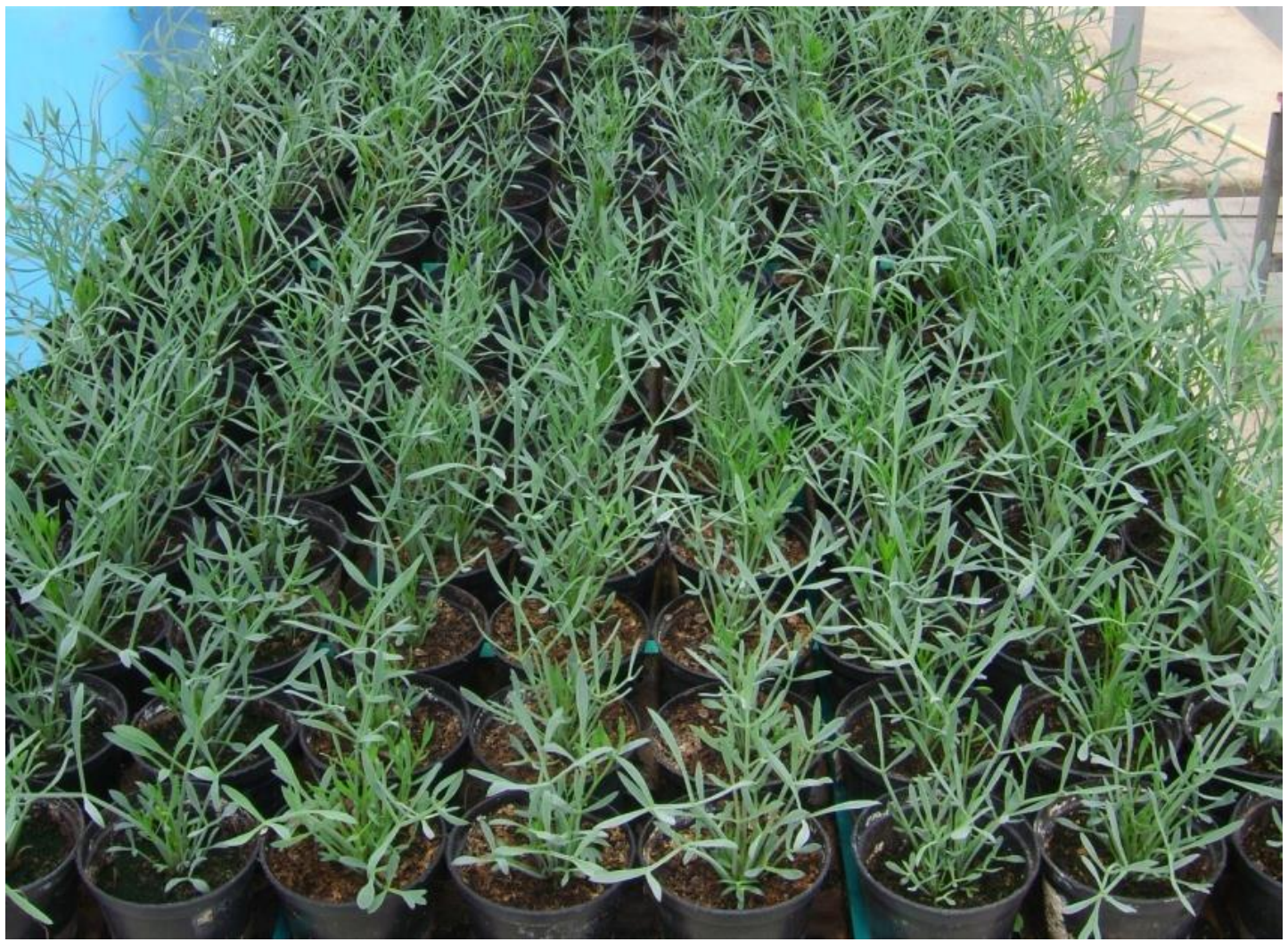

Figure 6. Potted sea fennel grown by using different posidonia compost-based substrates in comparison with peat [8].

A lower sea fennel biomass production was found in other studies with values ranging from 2.1 to $3.0 \mathrm{~g}$ DW plant $^{-1}[13,14]$. Besides these studies, to the best of our knowledge, the literature lacks other information with regards to the cultivation of sea fennel.

In this regard, considering the differences in the mineral composition between wild and cultivated sea fennel plants [22], future research activities could be carried out with the aim to evaluate the effect of cultivation techniques on yield and quality of this facultative halophyte. For example, the use of different nutrient solutions for soilless production of sea fennel could be a useful way to affect the mineral composition in plant tissue and for biofortification purposes [55-58]. In this context, the implementation of a biofortification process in sea fennel cultivation could be carried out for improving its nutritional value. Being a facultative halophyte, it could also be useful assessing the effect of saline stress on minerals enrichment in sea fennel grown by soilless systems [59]. Finally, since data about open-field cultivation of sea fennel is not present in literature, the influence of soil composition and salinity on this cropping system should be evaluated to optimize yield and nutritional quality of this facultative halophyte. 


\section{Prospects}

Apart from the nutritional traits and biological activity of sea fennel, several contributions are reported in literature regarding some culinary and folk uses of different sea fennel-based products (Table 5). Therefore, in order to evaluate whether sea fennel can be regarded as an emerging vegetable crop with a concrete chance to succeed, a SWOT analysis was performed. SWOT (Strengths, Weaknesses, Opportunities and Threats) analysis comprises the analysis of the strengths and weaknesses of a project, product, place or person and their relationship with the opportunities and threats of the surroundings. In short, it is a framework for identifying and analyzing the internal and external factors that can have an impact on the viability of a project, product, place or person. SWOT analysis could be considered as an important support tool for decision-making and is often used as a way to systematically analyze the internal and external environments of project, products and organizations. Table 6 reports the SWOT analysis regarding the exploitation of sea fennel as an alternative cash crop.

Table 5. Literature regarding some uses of different sea fennel-based products.

\begin{tabular}{ccc}
\hline Uses & Product Type & References \\
\hline Agri-food & Pickled leaves & Renna et al. [2] \\
\hline Aromatic herb & Potted plant & Montesano et al. [6] \\
\hline Folk medicine & Fresh leaves & Atia et al. [1] \\
\hline Folk medicine & Fruits infusion & Pavela et al. [19] \\
\hline Folk medicine & Pickled leaves & Carrió and Vallès [16] \\
\hline Folk medicine & Plant decotion & $\begin{array}{c}\text { Cornara et al. [17] } \\
\text { Savo et al. [18] }\end{array}$ \\
\hline Folk medicine & Plant juice & Pavela et al. [19] \\
\hline Food colorant & Dehydrated leaves & $\begin{array}{c}\text { Renna et al. [2] } \\
\text { Renna and Gonnella [21] }\end{array}$ \\
\hline Gastronomy & Fresh-cut leaves & KopperCress [20] \\
\hline Spice & Dehydrated leaves & $\begin{array}{c}\text { Renna et al. [2] } \\
\text { Renna and Gonnella [21] } \\
\text { Giungato et al. [60] }\end{array}$ \\
\hline
\end{tabular}

Table 6. SWOT analysis related to the exploitation of sea fennel as an alternative cash crop.

\begin{tabular}{ll}
\hline Strengths & Weaknesses \\
\hline $\begin{array}{l}\text { - Traditional product } \\
\text { - Good nutritional traits and taste }\end{array}$ & $\begin{array}{l}\text { - Knowledge limited to local areas and researchers } \\
\text { - Richness in chemical compounds market } \\
\text { - Halophyte }\end{array}$ \\
\hline Opportunities & Threats \\
\hline - Innovative products & $\bullet$ Resistance by consumers and farmers \\
- Slow Food Presidia & \\
\hline Consortia for R\&D & \\
\hline
\end{tabular}

Regarding the strengths, it is important to first specify that sea fennel is a traditional food used for making various dishes and processed products. This halophyte shows interesting nutritional traits and taste; moreover, it is very appreciated as a functional food. Therefore, the development of a specific agri-food chain based on new processed sea fennel products could meet the demand for local functional food from growing markets. By contrast, the interesting traits of sea fennel as well as its use as a food are known only by researchers through scientific literature or by a small percentage of people in niche areas. Moreover, it must be highlighted that currently there is only a little market niche for sea fennel. These weaknesses require specific activities to be carried out in order to disseminate knowledge, 
promote potential uses and boost consumer demand. In this context, sea fennel exploitation could be carried out by a multi-disciplinary approach and integrated projects, such in the case of Slow Food Presidia [61].

Being a halophyte with great adaptation to salinization, sea fennel can be considered an alternative for both horticultural and industrial crops also in the case of low quality soils and/or the availability of irrigation water with high electrical conductivity. Moreover, this species can be proposed also as a potted plant by using sustainable growing media instead of peat-based substrates. Unfortunately, the cultivation of this halophyte is currently very limited, and therefore more knowledge and technical solutions are needed before any large-scale diffusion.

Thanks to its richness of health-promoting components, sea fennel seems to be a very promising candidate for both pharmaceutical and food industry in order to produce new functional products. At the same time, the richness in chemical compounds make this halophyte also interesting for industrial production of botanical insecticides and other crop protection products. At any rate, according to Petropoulos et al. [62], a multi-step approach could be need for hypothesizing a full commercialization of these new products. In this context, the evaluation of several sea fennel populations from different geographical areas should be firstly carried out in order to select the best chemotypes for specific uses. At the same time, it could be needed also an evaluation of the potential differences regarding bioactive compounds content of plants under commercial cultivation conditions with respect to wild plants or ones grown under experimental conditions. On the other hand, some threats may also arise due to the potential resistance of consumers and farmers regarding this species as functional food and/or new cash crop. This may require a few preventive activities including clinical trials for evaluating effects on health and a specific marketing project to achieve increased consumer acceptance [62]. In this context, the establishment of consortia between research institutes, business companies and governmental organizations aiming to carried out these research and development activities, could be a good opportunity.

\section{Conclusions}

Current knowledge suggests sea fennel shows good potential as an emerging crop, being a refined food and also an interesting source of human health compounds and crop protection products. Moreover, sea fennel may be an alternative for both horticultural and industrial crops when in the presence of low quality soils and/or availability of irrigation water with high electrical conductivity. Nevertheless, more knowledge is needed before any large-scale diffusion, including chemical composition depending on the geographical origin as well as the effect of commercial cultivation on yield and quality. Therefore, new research and development activities should be carried out in order to increase consumer and farmer acceptance of this species as a new functional food and/or alternative crop.

Funding: This research was funded by Intervento cofinanziato dal Fondo di Sviluppo e Coesione 2007-2013-APQ Ricerca Regione Puglia "Programma regionale a sostegno della specializzazione intelligente e della sostenibilità sociale ed ambientale-FutureInResearch" - project 'Innovazioni di prodotto e di processo per la valorizzazione della Biodiversità Orticola pugliese (InnoBiOrt)'.

Acknowledgments: The author would like to thank Pietro Santamaria for his helpful comment on this review.

Conflicts of Interest: The author declares no conflict of interest.

\section{References}

1. Atia, A.; Barhoumi, Z.; Mokded, R.; Abdelly, C.; Smaoui, A. Environmental eco-physiology and economical potential of the halophyte Crithmum maritimum L. (Apiaceae). J. Med. Plants Res. 2011, 5, 3564-3571.

2. Renna, M.; Gonnella, M.; Caretto, S.; Mita, G.; Serio, F. Sea fennel (Crithmum maritimum L.): From underutilized crop to new dried product for food use. Genet. Resour. Crop Evol. 2017, 64, 205-216. [CrossRef]

3. Özcan, M.; Akgül, A.; Başcr, K.H.C.; Özck, T.; Tabanca, N. Essential oil composition of sea fennel (Crithmum maritimum) form Turkey. Nahrung Food 2001, 45, 353-356. [CrossRef] 
4. Pateira, L.; Nogueira, T.; Antunes, A.; Venâncio, F.; Tavares, R.; Capelo, J. Two chemotypes of Crithmum maritimum L. from Portugal. Flavour Fragr. J. 1999, 14, 333-343. [CrossRef]

5. Zarrouk, M.; El Almi, H.; Ben Youssef, N.; Sleimi, N.; Ben Miled, D.; Smaoui, A.; Abdelly, C. Lipid composition of seeds of local halophytes: Cakile maritima, Zygophyllum album and Crithmum maritimum. In Cash Crop Halophytes: Recent Studies; Lieth, H., Ed.; Springer: Dordrecht, The Netherlands, 2003; pp. 121-122.

6. Montesano, F.F.; Gattullo, C.E.; Parente, A.; Terzano, R.; Renna, M. Cultivation of potted sea fennel, an emerging mediterranean halophyte, using a renewable seaweed-based material as a peat substitute. Agriculture 2018, 8, 96. [CrossRef]

7. Slama, I.; Abdelly, C.; Bouchereau, A.; Flowers, T.; Savouré, A. Diversity, distribution and roles of osmoprotective compounds accumulated in halophytes under abiotic stress. Ann. Bot. 2015, 115, 433-447. [CrossRef] [PubMed]

8. Panta, S.; Flowers, T.; Lane, P.; Doyle, R.; Haros, G.; Shabala, S. Halophyte agriculture: Success stories. Environ. Exp. Bot. 2014, 107, 71-83. [CrossRef]

9. Atia, A.; Debez, A.; Barhoumi, Z.; Abdelly, C.; Smaoui, A. Histochemical localization of essential oils and bioactive substances in the seed coat of the halophyte Crithmum maritimum L. (Apiaceae). J. Plant Biol. 2009, 52, 448-452. [CrossRef]

10. Atia, A.; Ben Hamed, K.; Debez, A.; Abdelly, C. Salt and seawater effects on the germination of Crithmum maritimum. In Biosaline Agriculture and Salinity Tolerance in Plants; Birkhäuser Basel: Basel, Switzerland, 2006; pp. 29-33.

11. Atia, A.; Debez, A.; Barhoumi, Z.; Pacini, E.; Abdelly, C.; Smaoui, A. The mericarp of the halophyte Crithmum maritimum (Apiaceae): Structural features, germination, and salt distribution. Biologia 2010, 65, 489-495. [CrossRef]

12. Hamed, K.B.; Debez, A.; Chibani, F.; Abdelly, C. Salt response of Crithmum maritimum, an oleagineous halophyte. Trop. Ecol. 2004, 45, 151-159.

13. Ben Amor, N.; Ben Hamed, K.; Debez, A.; Grignon, C.; Abdelly, C. Physiological and antioxidant responses of the perennial halophyte Crithmum maritimum to salinity. Plant Sci. 2005, 168, 889-899. [CrossRef]

14. Ben Hamed, K.; Castagna, A.; Salem, E.; Ranieri, A.; Abdelly, C. Sea fennel (Crithmum maritimum L.) under salinity conditions: A comparison of leaf and root antioxidant responses. Plant Growth Regul. 2007, 53, 185-194. [CrossRef]

15. Franke, W. Vitamin C in sea fennel (Crithmum maritimum), an edible wild plant. Econ. Bot. 1982, 36, $163-165$. [CrossRef]

16. Carrió, E.; Vallès, J. Ethnobotany of medicinal plants used in Eastern Mallorca (Balearic Islands, Mediterranean Sea). J. Ethnopharmacol. 2012, 141, 1021-1040. [CrossRef] [PubMed]

17. Cornara, L.; La Rocca, A.; Marsili, S.; Mariotti, M.G. Traditional uses of plants in the Eastern Riviera (Liguria, Italy). J. Ethnopharmacol. 2009, 125, 16-30. [CrossRef] [PubMed]

18. Savo, V.; Giulia, C.; Maria, G.P.; David, R. Folk phytotherapy of the Amalfi Coast (Campania, Southern Italy). J. Ethnopharmacol. 2011, 135, 376-392. [CrossRef] [PubMed]

19. Pavela, R.; Maggi, F.; Lupidi, G.; Cianfaglione, K.; Dauvergne, X.; Bruno, M.; Benelli, G. Efficacy of sea fennel (Crithmum maritimum L., Apiaceae) essential oils against Culex quinquefasciatus Say and Spodoptera littoralis (Boisd.). Ind. Crops Prod. 2017, 109, 603-610. [CrossRef]

20. Sea Fennel | Koppert Cress Italy. Available online: https://centraleurope.koppertcress.com/en/content/ sea-fennel (accessed on 29 July 2018).

21. Renna, M.; Gonnella, M. The use of the sea fennel as a new spice-colorant in culinary preparations. Int. J. Gastron. Food Sci. 2012, 1, 111-115. [CrossRef]

22. Bianco, V.V.; Renna, M.; Santamaria, P. Ortaggi liberati - Dieci prodotti straordinari della biodiversità pugliese; Università degli Studi di Bari: Bari, Italy, 2018; ISBN 978866290285.

23. Burczyk, J.; Wierzchowska-Renke, K.; Głowniak, K.; Głowniak, P.; Marek, D. Geographic and environmental influences on the variation of essential oil and coumarins in Crithmum maritimum L. J. Herbs Spices Med. Plants 2002, 9, 305-311. [CrossRef]

24. Katsouri, E.; Demetzos, C.; Perdetzoglou, D.; Loukis, A. An interpopulation study of the essential oils of various parts of Crithmum maritimum L. growing in Amorgos Island, Greece. J. Essent. Oil Res. 2001, 13, 303-308. [CrossRef] 
25. Glamoclija, J.; Sokovic, M.; Grubisic, D.; Vukojevic, J.; Milinekovic, I.; Ristic, M. Antifungal activity of Critmum maritimum essential oil and its components against mushroom pathogen Mycogone perniciosa. Chem. Nat. Compd. 2009, 45, 96-97. [CrossRef]

26. Tsoukatou, M.; Tsitsimpikou, C.; Vagias, C.; Roussis, V. Chemical intra-Mediterranean variation and insecticidal activity of Crithmum maritimum. Z. Naturforsch. C 2001, 56, 211-215. [CrossRef] [PubMed]

27. Senatore, F.; Napolitano, F.; Ozcan, M. Composition and antibacterial activity of the essential oil from Crithmum maritimum L. (Apiaceae) growing wild in Turkey. Flavour Fragr. J. 2000, 15, 186-189. [CrossRef]

28. Coiffard, L.; Piron-Frenet, M.; Amicel, L. Geographical variations of the constituents of the essential oil of Crithmum maritimum L., Apiaceae. Int. J. Cosmet. Sci. 1993, 15, 15-21. [CrossRef] [PubMed]

29. Baser, K.H.C.; Özek, T.; Demirci, B.; Saritas, Y. Essential oil of Crithmum maritimum L. from Turkey. J. Essent. Oil Res. 2000, 12, 424-426. [CrossRef]

30. Polatoğlu, K.; Karakoç, Ö.C.; Yücel Yücel, Y.; Gücel, S.; Demirci, B.; Başer, K.H.C.; Demirci, F. Insecticidal activity of edible Crithmum maritimum L. essential oil against Coleopteran and Lepidopteran insects. Ind. Crops Prod. 2016, 89, 383-389. [CrossRef]

31. Barroso, J.G.; Pedro, L.G.; Figueiredo, A.C.; Pais, M.S.S.; Scheffer, J.J.C. Seasonal variation in the composition of the essential oil of Crithmum maritimum L. Flavour Fragr. J. 1992, 7, 147-150. [CrossRef]

32. Jallali, I.; Zaouali, Y.; Missaoui, I.; Smeoui, A.; Abdelly, C.; Ksouri, R. Variability of antioxidant and antibacterial effects of essential oils and acetonic extracts of two edible halophytes: Crithmum maritimum L. and Inula crithmoïdes L. Food Chem. 2014, 145, 1031-1038. [CrossRef] [PubMed]

33. Guil-Guerrero, J.L.; Rodríguez-García, I. Lipids classes, fatty acids and carotenes of the leaves of six edible wild plants. Eur. Food Res. Technol. 1999, 209, 313-316. [CrossRef]

34. Houta, O.; Akrout, A.; Neffati, M.; Amri, H. Phenolic contents, antioxidant and antimicrobial potentials of Crithmum maritimum cultivated in Tunisia arid zones. J. Biol. Act. Prod. Nat. 2011, 1, 138-143. [CrossRef]

35. Males, Z.; Zuntar, I.; Nigović, B.; Plazibat, M.; Vundać, V.B. Quantitative analysis of the polyphenols of the aerial parts of rock samphire-Crithmum maritimum L. Acta Pharm. 2003, 53, 139-144. [PubMed]

36. Meot-Duros, L.; Magné, C. Antioxidant activity and phenol content of Crithmum maritimum L. leaves. Plant Physiol. Biochem. 2009, 47, 37-41. [CrossRef] [PubMed]

37. Jallali, I.; Megdiche, W.; M’Hamdi, B.; Oueslati, S.; Smaoui, A.; Abdelly, C.; Ksouri, R. Changes in phenolic composition and antioxidant activities of the edible halophyte Crithmum maritimum L. with physiological stage and extraction method. Acta Physiol. Plant. 2012, 34, 1451-1459. [CrossRef]

38. Generalić Mekinić, I.; Šimat, V.; Ljubenkov, I.; Burčul, F.; Grga, M.; Mihajlovski, M.; Lončar, R.; Katalinić, V.; Skroza, D. Influence of the vegetation period on sea fennel, Crithmum maritimum L. (Apiaceae), phenolic composition, antioxidant and anticholinesterase activities. Ind. Crops Prod. 2018, 124, 947-953. [CrossRef]

39. Cornara, L.; D'Arrigo, C.; Pioli, F.; Borghesi, B.; Bottino, C.; Patrone, E.; Mariotti, M.G. Micromorphological investigation on the leaves of the rock samphire (Crithmum maritimum L.): Occurrence of hesperidin and diosmin crystals. Plant Biosyst. Int. J. Deal. Asp. Plant Biol. 2009, 143, $283-292$.

40. Meot-Duros, L.; Cérantola, S.; Talarmin, H.; Le Meur, C.; Le Floch, G.; Magné, C. New antibacterial and cytotoxic activities of falcarindiol isolated in Crithmum maritimum L. leaf extract. Food Chem. Toxicol. 2010, 48, 553-557. [CrossRef] [PubMed]

41. Costa, C.; Padalino, L.; Spinelli, S.; Serio, F.; Del Nobile, M.A.; Conte, A. Study of the efficacy of two extraction techniques from Crithmum maritimum and Salicornia europaea. J. Food Nutr. Res. 2018, 6, 456-463.

42. Kulisic-Bilusic, T.; Blažević, I.; Dejanović, B.; Miloš, M.; Pifat, G. Evaluation of the antioxidant activity of essential oils from caper (Capparis spinosa) and sea fennel (Crithmum maritimum) by diferent methods. J. Food Biochem. 2010, 34, 286-302. [CrossRef]

43. Pereira, C.G.; Barreira, L.; da Rosa Neng, N.; Nogueira, J.M.F.; Marques, C.; Santos, T.F.; Varela, J.; Custódio, L. Searching for new sources of innovative products for the food industry within halophyte aromatic plants: In vitro antioxidant activity and phenolic and mineral contents of infusions and decoctions of Crithmum maritimum L. Food Chem. Toxicol. 2017, 107, 581-589. [CrossRef] [PubMed]

44. Loizzo, M.R.; Tundis, R.; Bonesi, M.; Menichini, F.; Mastellone, V.; Avallone, L.; Menichini, F. Radical scavenging, antioxidant and metal chelating activities of Annona cherimola Mill. (cherimoya) peel and pulp in relation to their total phenolic and total flavonoid contents. J. Food Compos. Anal. 2012, 25, 179-184. [CrossRef] 
45. Generalić Mekinić, I.; Blažević, I.; Mudnić, I.; Burčul, F.; Grga, M.; Skroza, D.; Jerčić, I.; Ljubenkov, I.; Boban, M.; Miloš, M.; Katalinić, V. Sea fennel (Crithmum maritimum L.): Phytochemical profile, antioxidative, cholinesterase inhibitory and vasodilatory activity. J. Food Sci. Technol. 2016, 53, 3104-3112. [CrossRef] [PubMed]

46. Meot-Duros, L.; Le Floch, G.; Magné, C. Radical scavenging, antioxidant and antimicrobial activities of halophytic species. J. Ethnopharmacol. 2008, 116, 258-262. [CrossRef] [PubMed]

47. Ngahang Kamte, S.L.; Ranjbarian, F.; Cianfaglione, K.; Sut, S.; Dall'Acqua, S.; Bruno, M.; Afshar, F.H.; Iannarelli, R.; Benelli, G.; Cappellacci, L.; et al. Identification of highly effective antitrypanosomal compounds in essential oils from the Apiaceae family. Ecotoxicol. Environ. Saf. 2018, 156, 154-165. [CrossRef] [PubMed]

48. Viegi, L.; Pieroni, A.; Guarrera, P.M.; Vangelisti, R. A review of plants used in folk veterinary medicine in Italy as basis for a databank. J. Ethnopharmacol. 2003, 89, 221-244. [CrossRef] [PubMed]

49. Okusanya, O.T. The effect of sea water and temperature on the germination behaviour of Crithmum maritimum. Physiol. Plant. 1977, 41, 265-267. [CrossRef]

50. Marchioni-Ortu, A.; Bocchieri, E. A study of the germination responses of a Sardinian population of sea fennel (Crithmum maritimum). Can. J. Bot. 1984, 62, 1832-1835. [CrossRef]

51. Atia, A.; Debez, A.; Barhoumi, Z.; Smaoui, A.; Abdelly, C. ABA, GA3, and nitrate may control seed germination of Crithmum maritimum (Apiaceae) under saline conditions. C. R. Biol. 2009, 332, 704-710. [CrossRef] [PubMed]

52. Meot-Duros, L.; Magné, C. Effect of salinity and chemical factors on seed germination in the halophyte Crithmum maritimum L. Plant Soil 2008, 313, 83-87. [CrossRef]

53. Sveučilište u, Z.; Agronomski fakultet, A.; Lazarević, B.; Petek, M.; Vidak, M.; Šatović, Z.; Stanko, K.C. Poljoprivredna Znanstvena Smotra = Agriculturae Conspectus Scientificus: ACS; Faculty of Agriculture, University of Zagreb: Zagreb, Croatia, 2018; Volume 83.

54. Grigoriadou, K.; Maloupa, E. Micropropagation and salt tolerance of in vitro grown Crithmum maritimum L. Plant Cell Tissue Organ Cult. 2008, 94, 209-217. [CrossRef]

55. D'Imperio, M.; Renna, M.; Cardinali, A.; Buttaro, D.; Santamaria, P.; Serio, F. Silicon biofortification of leafy vegetables and its bioaccessibility in the edible parts. J. Sci. Food Agric. 2016, 96, 751-756. [CrossRef] [PubMed]

56. D’Imperio, M.; Renna, M.; Cardinali, A.; Buttaro, D.; Serio, F.; Santamaria, P. Calcium biofortification and bioaccessibility in soilless "baby leaf" vegetable production. Food Chem. 2016, 213, 149-156. [CrossRef] [PubMed]

57. Montesano, F.F.; D'Imperio, M.; Parente, A.; Cardinali, A.; Renna, M.; Serio, F. Green bean biofortification for Si through soilless cultivation: Plant response and Si bioaccessibility in pods. Sci. Rep. 2016, 6, 1-9. [CrossRef] [PubMed]

58. Signore, A.; Renna, M.; D’Imperio, M.; Serio, F.; Santamaria, P. Preliminary evidences of biofortification with iodine of "Carota di Polignano," an Italian carrot landrace. Front. Plant Sci. 2018, 9, 1-8. [CrossRef] [PubMed]

59. D'Imperio, M.; Montesano, F.F.; Renna, M.; Leoni, B.; Buttaro, D.; Parente, A.; Serio, F. NaCl stress enhances silicon tissue enrichment of hydroponic "baby leaf" chicory under biofortification process. Sci. Hortic. (Amsterdam) 2018, 235, 258-263. [CrossRef]

60. Giungato, P.; Renna, M.; Rana, R.; Licen, S.; Barbieri, P. Characterization of dried and freeze-dried sea fennel (Crithmum maritimum L.) samples with headspace gas-chromatography/mass spectrometry and evaluation of an electronic nose discrimination potential. Food Res. Int. 2018 (on line published). [CrossRef]

61. Slow Food Presidia-What We Do-Slow Food Foundation. Available online: https://www. fondazioneslowfood.com/en/what-we-do/slow-food-presidia/ (accessed on 29 July 2018).

62. Petropoulos, S.A.; Karkanis, A.; Martins, N.; Ferreira, I.C.F.R. Edible halophytes of the Mediterranean basin: Potential candidates for novel food products. Trends Food Sci. Technol. 2018, 74, 69-84. [CrossRef]

(C) 2018 by the author. Licensee MDPI, Basel, Switzerland. This article is an open access article distributed under the terms and conditions of the Creative Commons Attribution (CC BY) license (http:/ / creativecommons.org/licenses/by/4.0/). 